\title{
ÚJ MEGOLDÁSOK A FOGYASZTÓI MAGATARTÁS TENDENCIÁINAK VIZSGÁLATÁRA
}

\author{
KORREFERÁTUM TÖRŐCSIK MÁRIA „A FOGYASZTÓI \\ MAGATARTÁS ÚJ TENDENCIÁI" CÍMÜ MÜVÉHEZ
}

Töröcsik Mária „A fogyasztói magatartás új tendenciái” címú munkájában egy átfogó betekintést ad a posztmodern fogyasztói társadalomba. E világban a dinamikusan változó környezethez alkalmazkodni igyekvő, vágyai és félelmei által vezérelt fogyasztó képe rajzolódik ki, akit folyamatos megfelelni és megmutatni akarás, valamint a József Attila-i ,elvegyültem és kiváltam” érzés jellemez.

A szerzó jelen tanulmányában további szempontokkal kívánja kiegészíteni a Törő́csik Mária megállapításait, így közelebb jutva az általa feltett kérdések megválaszolásához. E célból a fogyasztói magatartás nemzetközi szakirodalmi trendjeit veti össze Törőcsik megállapításaival, illetve egy új fogyasztói trendkutatási eszköz, a Google Trends alkalmazását mutatja be. Teszi ezt azzal a szándékkal, hogy Törőcsik gondolatait alátámassza, illetve kiegészítse az általa meghatározott célrendszerhez igazodóan, miszerint: „Tegyünk most kísérletet arra, hogy a marketinggondolkodás jellemzöit, a kutatók publikációs tevékenységének súrüsödési pontjait, a gyakorlat megoldásra váró kérdéseit és reakcióit vegyuik sorra."

\section{Kulcsszavak: fogyasztói magatartás, trendkutatás, marketingkutatási-módszertan}

Törőcsik tanulmányában foglalkozik azzal, miként alakul a marketing, és a marketing főbb témáit tekintve meghatároz egy releváns fejlődési vonulatot, melyet az alábbiakban nemzetközi szakirodalmi kontextusba helyezve kívánok validálni. Ehhez a fogyasztói magatartás tudományterületének legfontosabb folyóiratában, a Journal of Consumer Research-ben az elmúlt 40 évben megjelent 16 fó téma idôbeli változását mutatom be Wang és szerzőtársainak (2015) munkájára támaszkodva, akik a folyóirat elmúlt 40 évének minden számát megvizsgálták adatbányászati módszerrel. A témák népszerúségének változását az 1 . ábra szemlélteti.
A fogyasztói magatartás témáinak alakulása az elmúlt 40 évben a Journal of Consumer Research-ben

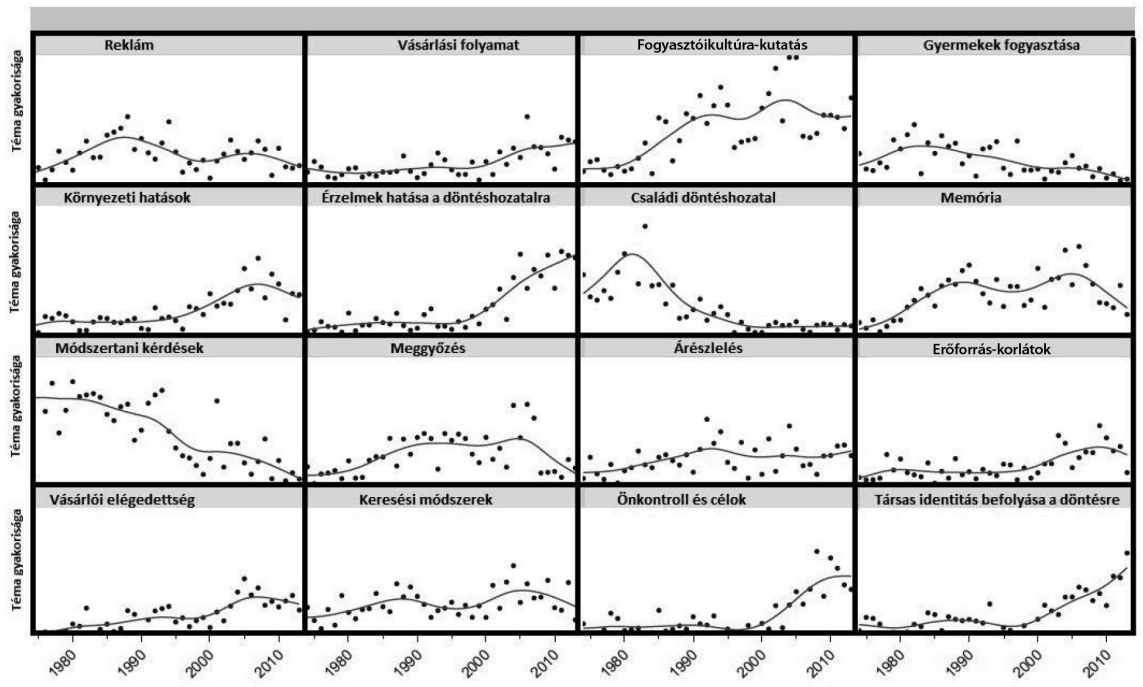

Forrás: Wang et al. $(2015, p$. 11.) alapján saját szerkesztés 
A fent említett, Törőcsik által meghatározott „,releváns fejlödési vonulatot" összevetve az 1. ábrán illusztrált témák időbeli alakulásával, igazolhatjuk Törőcsik gondolatmenetét az alábbiak szerint (dôlttel szedve Törőcsik gondolata, zárójelben az 1. ábrán lévő témák időbeli alakulása): „kezdtünk a meglévó termékek forgalmát generáló reklámmal („reklám” kiugró, majd csökkenő jelentősége), a reklámértelmezésekkel, hatásvizsgálatokkal („,meggyő́zés” és „memória” változó, de csökkent a jelentósége). Majd jöttek a termékek, fóképp az új termékek, az innovációk, a termékdöntések, az életgörbe-vizsgálatok („,családi döntéshozatal” kiugró, majd eltúnő jelentősége). Ezután a kapcsolódó és önállósuló szolgáltatások ideje következett az elégedettséggel (,vásárlói elégedettség” növekvő jelentőséggel), a vevöérték kidolgozásával, majd következett az élmények kiemelése (,érzelmek hatása a döntéshozatalra" kiugró jelentősége),, az on-line és az off-line média és az ambient marketing által közvetített izgalommal (,környezeti hatások” növekvo jelentősége), ma pedig az „emberfogyasztás” jelent meg” az (,önkontroll és célok”, valamint a „társas identitás befolyásának” kiugró jelentősége). A fentiek tükrében a Journal of Consumer Researchben feldolgozott témák alakulása igazolta Törőcsik gondolatmenetét - talán csak az innovációk esetében érezhetünk némi bizonytalanságot.

Törőcsik a félelem, a szegénység és a lecsúszás témáinak vizsgálata során veti fel, hogy vajon a marketing akkor egy alapvetóen pozitív beállítottsággal jellemezhetö tudományterület, vagy a szakma csak negligál problémákat, kevésbé attraktív csoportokat. Ennek vizsgálatához szintén a Journal of Consumer Research elemzéséhez nyúlok, azonban immáron más szempontból, az egyes marketingterületek idóbeli alakulása helyett általánosan a szakmai közvélemény által vizsgált témákat, csoportokat és alkalmazott módszereket mutatom be. Ehhez Rapp és Hill (2014) tanulmányára támaszkodom, akik vizsgálatuk során az elmúlt 40 év összes Journal of Consumer Research cikkét négy dimenzió mentén kategorizálták: a vizsgált téma, a módszertan, a minta és a kutatás helyszíne. Eredményeiket az 1. táblázat szemlélteti.

\section{A Journal of Consumer Research elmúlt 40 évben megjelent cikkeinek sajátosságai}

\begin{tabular}{|c|c|c|}
\hline Vizsgálati szempont & Gyakoriság & Népszerúsége az elmúlt 40 évben \\
\hline \multicolumn{3}{|l|}{ A cikk tématerülete } \\
\hline Marketingmenedzsment & 619 & Csökkent \\
\hline Fogyasztói választás és döntéshozatal & $1045^{* *}$ & Tovább növelte dominanciáját \\
\hline Alkalmazott fogyasztói magatartás és közpolitika & 221 & Visszaesés után újra magára talált \\
\hline Szociológiai perspektívák & 397 & Növekedett \\
\hline Módszertani témák & 120 & Csökkent \\
\hline \multicolumn{3}{|l|}{ A cikkben alkalmazott módszertan } \\
\hline Kvalitatív kutatás & 212 & Stagnált \\
\hline Kvantitatív kutatás & 457 & Csökkent \\
\hline Kísérletes módszertan & $1129^{* *}$ & Dinamikusan növekedett \\
\hline Koncepcionális modellalkotás & 172 & Csökkent \\
\hline Analitikus modellalkotás & 32 & Stagnált \\
\hline \multicolumn{3}{|l|}{ Minta } \\
\hline Egyetemi hallgatók & $1022^{* *}$ & Dinamikusan növekedett \\
\hline Általános társadalomi & 602 & Csökkenés után magára talált \\
\hline Témaspecifikus populáció & 249 & Csökkent \\
\hline \multicolumn{3}{|l|}{ A kutatás helyszíne } \\
\hline Fejlett országok* (pl. USA, Magyarország) & $1595^{* *}$ & Stagnált \\
\hline Közepesen fejlett országok (pl. Románia) & 17 & Stagnált \\
\hline Alacsonyan fejlett országok (pl. Thaiföld) & 40 & Stagnált \\
\hline Fejletlen országok (pl. Niger) & 3 & Stagnált \\
\hline
\end{tabular}

*A Szerzők itt a fejlettségre a „human development” kifejezést alkalmazták, az általános „fejlett országok” fogalomtól eltérő ez a kategória - például hazánk is ebben a kategóriában foglal helyet.

**Az alább elemzett sajátosságok. 
A fentiek alapján úgy tûnik, a Törôcsik által felvetett dilemma igenis valós, a kép pedig igen lehangolónak látszik. A fogyasztói magatartás kutatásain belül szinte kizárólag a fejlett országok fogyasztói döntéshozatalát vizsgálták specifikus populációk (pl. szegények, kisebbségek) helyett egyetemi hallgatókon, kísérletes módszertannal. Ez az eredmény felhívja a figyelmet arra is, hogy a fogyasztói magatartás kutatásának megállapításai gyakran kevésbé általánosíthatóak - különösen igaz ez, ha szúkebb, rejtettebb, illetve a társadalmi spektrum valamelyik szélén lévő csoportról van szó.

\section{A márkához kapcsolódó érzelmek elótérbe kerülése}

A fenti tematikus evolúciót végigkövetve egy sajátos helyzetképhez jutunk, mely Törőcsik megfogalmazásában a posztmodern a széttöredezettséget, egyben az elbizonytalanodást hozta magával. Ebben a világban a fogyasztók és a fogyasztás új értelmet nyert (Hetesi et al., 2007), a márkáknak egyre nagyobb a jelentőségük, de már nemcsak mint a minőség vagy státus jelzője (Belk, 1996; Holt, 1998), hanem mint a fogyasztóhoz kötődő szimbolikus entitások (Hofmeister-Tóth, 2008; Törőcsik, 2011).

A vásárlási döntések belül nô az emocionális tényezők döntésre gyakorolt hatásának aránya, egyre nagyobb jelentőséget kapnak a márkához fúződő érzelmek (Batra et al., 2012). A márkákhoz való érzelmi kötődés a szakirodalmon belül először a „márkaviszony-elmélet" (brand relationship theory) keretén belül jelent meg (Fournier, 1998), majd Roberts (2004) könyve nyomán a Lovemarks (szeretetmárkák) kifejezés által vált felkapottá. A márkaszeretetet a pozitív szájreklámmal, a márkalojalitással (Fournier, 1998), a magasabb rezervációs árral és a kellemetlen márkaélmények jobb tolerálásával hozzák összefüggésbe (Thomson et al., 2005). Az értelmezések azonban gyakran nem következetesek. Batra és szerzőtársai (2012) hívják fel a figyelmet arra, hogy e terület vizsgálatánál érdemes a márkaszeretetet elkülöníteni a személyekhez kapcsolódó szeretettől, továbbá ezt nem érzelemként (emotion), hanem kapcsolatként (relationship) kezelve, jobban meg tudjuk ragadni a lényegét. A márka lehet érzelem közvetítője is, például ajándékozás esetén. Fuchs és szerzőtársai (2015) ezt a kézmúves termékek kapcsán vizsgálták, és arra jutottak, hogy a fogyasztók pozitívabb attitúddel viseltetnek e termékek iránt, mivel azt érzik, hogy ezek szimbolikusan „szeretetet tartalmaznak”, így különösen alkalmasak szeretteinknek szánt ajándékként (Fuchs et al., 2015).

Érdemes azonban megemlíteni, hogy a márka-fogyasztó viszony nemcsak ilyen szívélyes kontextusban tud megjelenni. Kim és Kramer (2015) szerint a szokásosan vizsgált „márka, mint partner” viszony helyett érdemes a „márka, mint szolga” viszonyt is vizsgálni, hiszen ez utóbbi az antropomorfizált márkák esetében a vizsgált materialista fogyasztók esetében vonzóbb. Vagyis napjaink fogyasztói nem feltétlenül „,szeretetmárkákra” vágynak, hanem bizonyos esetekben „,szolgamárkákra" is.

A fogyasztói magatartás jellemző trendjeinek áttekintése után a következőkben e trendek feltárásához használható új eszköz bemutatásával kívánom Törőcsik további megállapításait kiegészíteni, illetve alátámasztani.

\section{A Google Trends, mint a trendkutatók ,barátja”}

Napjainkra a trendkutatások egy új forrással gyarapodtak. A XXI. század fogyasztója az on-line térben éli életének jelentős részét és az on-line közösséghez fordul tanácsért is. A „Google a barátod”, illetve a „megguglizom” általánosan ismert jelszavak jól jelzik ezt a dominanciát. A legújabb nemzetközi kutatások azonban a Google eszközeinek tudományos alkalmazhatóságát is bizonyították. Ginsberg és szerzôtársainak (2009) Nature-ben megjelent epidemiológiai témájú cikke volt az első nagyhatású írás e téren. A cikkben igazolták a járványterjedés és a betegséghez kapcsolódó tipikus Google keresőszavak összefüggéseit, vagyis azt, hogy a Google Trends alkamazás segítségével hatékonyan lehet monitorozni, sőt prognosztizálni a járvány (ki) alakulását. Az alkalmazást azóta sikeresen használták ingatlanpiaci előrejelzések (Wu - Brynjolfsson, 2009), lakossági kiadások alakulása (Vosen - Schmidt, 2011) és részvényárfolyamok prognózisa (Da et al., 2011) terén is.

2015-ben pedig Du és szerzőtársai (2015) marketingkutatási célú felhasználását is igazolták a Google Trends alkalmazásnak. A szerzók az autópiacon empirikusan igazolták, hogy az autó termékattribútumaira (fogyasztás, fenntartási költségek stb.) vonatkozó Google-keresések korrelálnak ezen attribútumok döntési folyamatban betöltött szerepének jelentőségével, így hatékony előrejelzói a fogyasztói döntéseknek.

Habár számos on-line kereséseket elemző szolgáltatás ismert (pl. attensity.com, converseOn.com, conversation.com), ezek közül mégis az ingyenesen elérhetó Google Trends a legalkalmasabb. Egyrészt azért, mert a Google a világ messze legdominánsabb keresôje (piaci részesedése szinte minden országban $80 \%$ feletti), így a világ on-line kereséseinek többsége e rendszeren keresztül zajlik. Másrészt azért, mert folyamatosan frissített, viszonylag jól kombinálható, naprakész adatokat kínál elemzésre.

E módszerrel Törőcsik azon állítását vizsgáltam, miszerint a magyar társadalom nagyobb hányada nagyon szúkös keretek között hozhat vásárlói döntése- 


\section{Google keresési szavak időbeli gyakorisága (szürke=Tesco; fekete=Olcsó; sötétszürke=Árgép)}

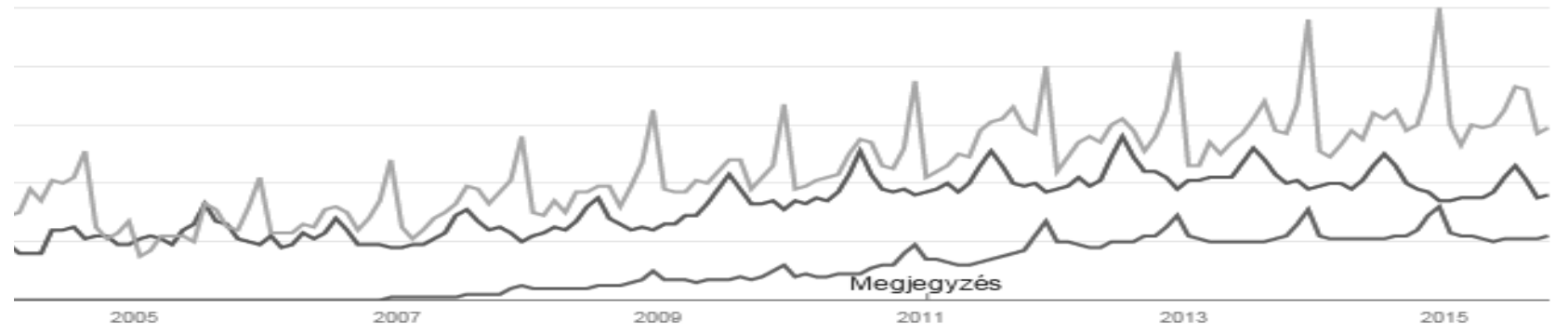

Megjegyzés: Az ábra függőleges tengelyén az adott szó relatív keresési gyakorisága szerepel

ket, és $a$ „kötelező” kiadások után vagy nem marad az ilyen háztartásokban szabadon elkölthetó pénz, vagy nagyon kevés, amivel nincs alkalom/lehetóség a fogyasztói élményeket megélni. A vizsgálathoz használt elemzést a 2.ábra illusztrálja.

A 2. ábrából több érdekesség kiolvasható. Egyfelól a válság óta 2013-ig folyamatosan növekedett az „olcsó" szó keresési gyakorisága, azóta azonban csökkent, míg a „Tesco” és az „árgép” növekedése folytatódott. Érdekes jelenség, hogy periodikus (évenkénti) kiugrás található a Tesco kulcsszónál pontosan akkor, amikor periodikus (évenkénti) zuhanás tapasztalható az „olcsó" szó esetén, mégpedig minden év decemberében, karácsonykor. Gondolhatnánk, hogy nem az ár alapján döntenek a fogyasztók szeretteiknek való ajándék keresésekor, azonban ha a képbe beillesztjük az „árgép”-et, akkor láthatjuk, hogy ott pont ekkor van szintén periodikus kiugrás. Ezt a jelenséget tehát úgy foglalhatjuk össze, hogy a fogyasztók általában olcsó termékeket keresnek, de karácsonykor inkább „kedvező árút”, azaz ekkor nem az abszolút olcsóság a döntő, hanem az, hogy az adott terméket hol lehet relatíve kedvezőbben megszerezni.

A fentiekkel egyfelől igazolni kívántam Törőcsik két megállapítását, másfelől egy olyan új trendelemzési módszertanra szerettem volna felhívni a figyelmet, mely - kétségtelenül létező korlátai ellenére - nemzetközileg egyre népszerúbb, így érdemes hazánkban is elgondolkodni alkalmazásán.

\section{Összegzés}

Összefoglalóan úgy vélem a marketing bár több, mint ötven éve igyekszik megérteni a fogyasztót, mégsem jutott sokkal közelebb a megoldáshoz. Ennek egyik oka, hogy maga a fogyasztó is folyamatos mozgásban, változásban van, igyekszik alkalmazkodni a dinamikusan változó környezetéhez. Úgy tủnik a fogyasztó „fekete doboza" továbbra is elnyel szinte minden kutatói fény- sugarat, hiába áll egyre több innovatív eszköz, megoldás és egyre jelentősebb felhalmozott tudás rendelkezésünkre.

Továbbra is nyitott kérdés, hogy miért ragaszkodik egy fogyasztó egy-egy márkához, miért és miként keres szeretetet és barátságot ennél a márkánál, miért várja gyártójától, hogy helyette vállaljon fenntarthatósági és társadalmi felelősséget, és miért érzi szükségét annak, hogy ebbéli szándékait mind újabb és újabb formában, illetve csatornákon juttassa kifejeződésre.

Törőcsik Mária tanulmányához kapcsolódó korreferátum elkészítése kiemelten megtisztelő felkérés volt számomra. Jelen tanulmányommal igyekeztem hozzájárulni az általa készített mú gazdagításához, melyről összességében azt gondolom, hogy napjaink legfrissebb nemzetközi tanulmányainak megállapításaival összecsengô tartalommal bír, így értékes áttekintése a hazai fogyasztói magatartás helyzetének.

\section{Lábjegyzet}

${ }^{1}$ A tanulmány az MTA Gazdálkodástudományi Bizottság Marketingtudományi Albizottságának vitaindító rendezvényén elhangzott előadásra alapul.

\section{Felhasznált irodalom}

Batra, R. - Ahuvia, A. - Bagozzi, R. P. (2012): Brand Love. Journal of Marketing, Vol. 76, No. 2: p. 1-16.

Belk, R. W. (1996): Studies in the New Consumer Behaviour. in: Miller, D. (ed): Acknowledging consumption. New York: Routledge: p. 58-95.

Da, Z. - Engelberg, J. - Gao, P. (2011): In Search of Attention. Journal of Finance, Vol 66, 5: p. 1461-1499.

$D u, R . Y .-H u, Y$. Damangir, S. (2015): Leveraging Trends in Online Searches for Product Features in Market Response Modeling. Journal of Marketing, Vol. 79,1: p. 29-43.

Fournier, S. (1998): Consumers and Their Brands: Developing Relationship Theory in Consumer Resear- 
ch. Journal of Consumer Research, Vol. 24: p. 343372.

Fuchs, C. - Schreier, M. - van Osselaer, S. M. J. (2015): The Handmade Effect: What's Love Got to Do with It? Journal of Marketing, Vol. 79, 2: p. 98-110.

Ginsberg, J. - Mohebbi, M. H. - Patel, R. S. - Brammer, L. - Smolinski, M. S. - Brilliant, L. (2009): Detecting Influenza Epidemics Using Search Engine Query Data. Nature, Vol. 457: p. 1012-1014.

Hetesi E. - Andics J. - Veres Z. (2007): Az életstílus kutatási eredmények fogyasztásszociológiai interpretációs dilemmái. Szociológiai Szemle, Vol. 17, 3-4.: p. 115-134.

Hofmeister-Tóth Á. (2008): A fogyasztói magatartás alapjai. Budapest: Aula Kiadó

Holt, D. B. (1998): Does Cultural Capital Structure American Consumption? Journal of Consumer Research, Vol. 25,1: p. 1 -25.

Kim, H. C. - Kramer, T. (2015): Do Materialists Prefer the "Brand-as-Servant"? The Interactive Effect of Anthropomorphized Brand Roles and Materialism on Consumer Responses. Journal of Consumer Research, Vol. 42, 2: p. 284-299.
Rapp, J. M. - Hill, R. P. (2015): Lordy, Lordy, Look Who's 40! The Journal of Consumer Research Reaches a Milestone. Journal of Consumer Research, Vol. 42, 1: p. 19-29.

Roberts, K. (2004): Lovemarks: the future beyond brands. New York: PowerHouse Books

Thomson, M. - MacInnis, D. J. - Park, C. W. (2005): The Ties That Bind: Measuring the Strength of Consumers' Emotional Attachments to Brands. Journal of Consumer Psychology, Vol. 15, 1: p. 77-91.

Törö́csik, M. (2011): Fogyasztói magatartás - Insight, trendek, vásárlók. Budapest: Akadémiai Kiadó

Vosen, S. - Schmidt, T. (2011): Forecasting Private Consumption: Survey-Based Indicators vs. Google Trends. Journal of Forecasting, Vol. 30, 6: p. 565-578.

Wang, X. S. - Bendle, N. T. - Mai, F. - Cotte, J. (2015): The Journal of Consumer Research at 40: A Historical Analysis. Journal of Consumer Research, Vol. 42, 1: p. 5-18.

Wu, L. - Brynjolfsson, E. (2009): The Future of Prediction: How Google Searches Foreshadow Housing Prices and Quantities. in: ICIS 2009 Proceedings, Paper 147, letölthető: http://aisel.aisnet.org/icis2009/147 